\title{
Turkish EFL Learners' Willingness to Communicate in L2 and Motivation
}

\author{
Cennet Altiner
}

Correspondence: Cennet Altiner, Lecturer, Uşak University, Turkey.

Received: August 29, 2018

doi:10.11114/jets.v6i11a.3815
Accepted: October 9, 2018

Online Published: November 29, 2018

URL: https://doi.org/10.11114/jets.v6i11a.3815

\begin{abstract}
Willingness to communicate in a second language has become an important area of research recently. However, different factors which influence learners' willingness to communicate have not been widely investigated in the Turkish classroom context. Motivation is considered as an important factor which has a direct influence on learners' willingness to communicate. Thus, this study will look into the relationship between English as a foreign language (EFL) learners' willingness to communicate (WTC) in Turkish EFL context and their motivation about English learning through the participation of 106 EFL students who were registered in the one-year preparatory school at Usak University, Turkey. Language Learning Orientation Scale and Willingness to Communicate Scale were adopted for the study. Descriptive statistics and simple linear regression analysis were carried out to find out the relationship between WTC and motivation. Findings indicated that participants were somewhat willing to communicate and there was a significant correlation between learners' WTC and motivation. The findings of this study is useful in terms of the pedagogical and theoretical implications which emphasize the role of motivation in encouraging L2 learners' willingness to communicate.
\end{abstract}

Keywords: ideal L2 self, willingness to communicate, EFL

\section{Introduction}

In order to acquire a language, necessary conditions should be met for learners. According to Krashen (1982), L2 learners should be provided with $i+1$ input which is a little more advanced level than the current state of the learner's interlanguage. Krashen (1982) suggests that speaking is a result of acquisition and it cannot be taught directly. It emerges on its own based on the competence acquired through comprehensible input. On the other hand, Swain (1985) claimed that learners cannot acquire a language without producing comprehensible output . She suggests that output gives learners the opportunity to notice gaps in their interlanguages and test hypotheses. Other researchers also supported Swain's Output Hypothesis. Long (1985) claimed that interacting in L2 is the obligatory condition for acquisition and he emphasized the importance of both input and output and mutual feedback in communication. Lightbown and Spada (1999) pointed out that it is impossible for learners to develop their oral skills if their language classrooms do not provide learners with opportunities for interaction.

From the perspective of L2 acquisition theories, learners should use the target language to learn it. However, not all of the learners have the same level of willingness to communicate in a classroom setting which could prevent successful L2 acquisition. So, it is necessary to investigate different factors which may affect learners' willingness to communicate. More studies on willingness to communicate and individual difference factors should be conducted to understand EFL learners' communication intentions. Therefore, the main goal of this study is to examine the effect of motivation as an individual factor on EFL learners' willingness to communicate in the Turkish context.

\section{Willingness to Communicate}

The construct "Willingness to Communicate" (WTC) was first proposed by McCroskey and Baer (1985) in relation to communication in the native language and it was defined as the intension to initiate communication when free to do so. McCroskey and Richmond (1991) suggest that WTC is a personality-based trait and people's tendencies to talk change significantly from one another. Besides, they claim that individuals show similar WTC tendencies although situational variables can influence one's willingness to communicate. Also, some variables such as introversion, self-esteem, communication competence, communication apprehension and cultural diversity were listed as factors that can cause differences in WTC.

In the 1990s, WTC research in L1 received the attention of the researchers in the second language research area. Some studies which combined WTC model with Gardner's (1985) socio-educational model was carried out in the Canadian 
contexts to investigate WTC in a L2. MacIntyre \& Charos's (1996) study was the first to investigate WTC in L2. MacIntyre's (1994) model was adopted in L2 by adding motivation, personality, and context to the structural model as the determinants of WTC. The relations among affective variables, such as perceived L2 competence, L2 anxiety, integrativeness and attitudes toward the learning situation, and their influence on the frequency of second language communication were investigated. The results showed that perceived communication competence has a direct impact on L2 communication frequency. Both perceived competence and anxiety directly affected WTC and personality traits, such as extraversion, agreeableness, conscientiousness, emotional stability, and intellect influenced motivation and WTC.

In 1998, a comprehensive model of willingness to communicate in L2 was suggested by MacIntyre, Clement, Dörnyei, and Noels based on the idea that WTC should be treated as as a situational variable instead of a trait-like variable. A pyramid figure which has twelve constructs was developed to illustrate the probable determinants of willingness to communicate in L2. The heuristic model proposed by MacIntyre, Clement, Dörnyei, and Noels (1998) is important because it is "the first attempt at a comprehensive treatment of WTC in the L2" (MacIntyre, Clement, Dörnyei, \& Noels, 1998, p. 552). Different aspects of this model have been investigated since its proposal in 1998.

In the Turkish context, research on willingness to communicate is quite limited. In 2005, Bektaş investigated to what extent Turkish university students are willing to communicate and whether the WTC model that she proposed can explain the relations among social-psychological, linguistic and communication variables in this context. Mixed-method approach which includes both quantitative and qualitative data collection and analysis was adopted in the study. Participants consisted of 356 university students in Turkey. Quantitative data was collected through a questionnaire and 15 randomly selected students were interviewed for qualitative data analysis. The results indicated that students' motivation to learn English personality indirectly influenced their WTC through linguistic self-confidence.

\section{Motivation}

L2 motivation is an important area in the second language acquisition research (Dörnyei \& Ushioda, 2009). Research in L2 motivation started with Gardner's socioeducational model (Gardner, 1985). Early L2WTC studies employed motivation and integrativeness as two important variables. However, integrative motivation caused problems in foreign language settings because learners in EFL settings have only classsroom environment to use the target language. Dörnyei (1990) also claims that EFL learners do not form attitudes toward the target community because they do not communicate with native speakers in real settings.

During the 1990s, cognitive and humanistic aspect of motivation caught the attention of researchers. Self-determination theory (SDT; Deci \& Ryan, 1985) is one of the most popular educational psychology theories. Self-determination theory started to gain importance during this time (Deci \& Ryan, 1985). Self-determination theory suggests that human beings basicly need autonomy, competence, and relatedness. Thus, to what extent these needs are satisfied causes various types of motivation (Deci \& Ryan, 2000).

The present study will utilize Noels and associates' (Noels, Pelletier, Clement, \& Vallerand, 2000) intrinsic and extrinsic motivation derived from self-determination theory in educational psychology (Deci \& Ryan, 1985) as an informative framework. Ryan's (1995) discussion of intrinsic and extrinsic motivation considers these constructs as orientations. Intrinsic orientations are directly related to one's inherent interest in the activity and the activity is performed to feel satisfied with it. Three different types of intrinsic orientations have been defined (Vallerand, Pelletier, Blais, Briere, Senecal, \& Valliires, 1992, 1993; Vallerans, 1997). Intrinsic-Knowledge involves the feelings of pleasure that is obtained from developing knowledge about a specific area. Intrinsic-Accomplishment is identified as the sense of enjoyment which is related with surpassing oneself and completing a difficult activity. The process of achievement is more important than the end result. Intrinsic-Stimulation is defined as the enjoyment of the aesthetics of the experience (Noels, Pelletier, Clement, \& Vallerand, 2000). Similarly, three types of extrinsic motivation was categorized in accordance with the Deci and Ryan's (1985) self-determination theory. External Regulation is defined as the performance of an activity controlled by external forces. Introjected Regulation, which is more internalized, refers to reasons related with carrying out an activity because of the pressure that learners put on themselves, so that they force themselved to conduct that activity. Identified Regulation, the most self-determined form of extrinsic motivation, is related with performing an activity due to its importance for attaining a valued goal or personally related reasons.

\section{Methodology}

The main goal of this study is to investigate willingness to communicate (WTC) in Turkish English-as-a-foreign-language (EFL) classrooms and to find out the predicting effect of motivation on L2WTC.

Research Question:

- What is relationship among L2WTC and motivation? 


\section{Participants}

This study was carried out at School of Foreign Languages at Uşak University, in Uşak, Turkey. Data was collected at the end of spring semester of the academic year 2015/2016. Study population was 106 preparatory students who were voluntarily choose to attend one-year preparatory school at Uşak University.

\section{Instruments}

Language Learning Orientation Scale and Willingness to Communicate Scale were adopted for the study. For the instruments, both translation and back translation methods were conducted to prevent any semantic loss (Brislin, 1980).

\section{Results}

The quantitative data were analyzed by using the Statistical Package for Social Sciences (SPSS) and the reliability coefficients of each part of the scale were found as the following: Willingness to Communicate (Ten Items) (Cronbach's alpha $=.87$ ), Motivation (21 Items) (Cronbach's alpha $=.91$

\section{The nature of the relationship between L2WTC and motivation}

Pearson correlation coefficients were calculated after the preliminary statistical analyses (e.g. control of normality and linearity) and it was found that both of the variables were correlated positively with each other at a statistically significant level.

Table 1. Relationship between L2WTC and motivation

\begin{tabular}{lllll}
\hline & 1 & 2 & 3 & 4 \\
\hline L2WTC & 1 & & \\
Motivation & $.455^{* *}$ & 1 & \\
\hline
\end{tabular}

**Correlation is significant at the 0.01 level (2-tailed).

It was found, as indicated in Table 1, that there was also a medium size correlation between L2WTC and motivation $(\mathrm{r}(106)=.455, \mathrm{p}<.01)$. This correlation also implies that motivation of language learners in the process of language learning would have a positive effect on their willingness to communicate in L2.

\section{Conclusion}

The present study mainly looked into the interrelationship between L2WTC and motivation. It mainly focused on if there is a predicting effect of learners' motivation on their WTC. The results of the study showed that high motivation, which was measured within the framework of extrinsic/intrinsic motivation, would influence participants' willingness to communicate, which supports the findings of many researchers such as MacIntyre and Clement (1986), Hashimoto (2002) and Jung (2011). For instance, Jung's (2011) study, which was conducted in the Korean context, examined the interrelationships among university students' WTC, self-perceived communication competence, communication apprehension, motivation, attitudes, and personality. According to the results of the SEM anlysis, self-perceived communication competence and motivation were found to be directly related to WTC. Besides, there was a direct path from motivation to self-perceived communication confidence. Attitudes indirectly influenced WTC. The paths from self-perceived communication confidence to WTC, motivation to confidence, and attitudes to motivation were also found in Yashima's (2002) and Kim's (2004) studies. However, previous research did not find the path from motivation to WTC (MacIntyre \& Charos, 1996; Yashima, 2002; Kim, 2004; Bektaş, 2005). The results of the qualitative data analysis also revealed that students consider their English communication confidence and motivation as the most important factors for their WTC in English.

This finding implied that the more motivated students become, the more willing they become to communicate in English. However, this situation was different in some of the previous studies which found that motivation was directly related to communication confidence and indirectly related to willingness to communicate through communication confidence (Ghonsooly et al., 2012; Kim, 2004; Peng \& Woodrow, 2010; Yashima, 2002). For example, Kim (2004) carried out a study with Korean EFL students in order to test the MacIntyre et al.' (1998) Model. Her study was a replication of Yashima (2002)'s study in a different setting. The results of the SEM analysis showed that students' confidence in English communication strongly affects their WTC and their attitudes and motivation indirectly affects their WTC through linguistic self-confidence. In the Turkish context, previous L2WTC studies, which were carried out by Bektaş (2005) and Öz (2016), also found that motivation indirectly influenced willingness to communicate through the mediation of communication confidence, which means that students' high motivation declines students' speaking anxiety, which, in turn, increases their communication competence and willingness to communicate. Considering these 
different findings of studies in term of the direct or indirect effect of motivation on willingness to communicate, it could be concluded that motivation is a significant antecedent for WTC in English despite different findings about direct or indirect effect of it on WTC in the literature.

Thus, it is strongly suggested that language teachers should try their best to enhance their learners' motivation for language learning, which, in turn, affect their learners' L2WTC levels. As opposed to many studies which indicated an indirect path from motivation to WTC through linguistic self-confidence, the correlation between motivation and WTC in this study put emphasis on the crucial effect of motivation on learners' WTC. In this study, learners' motivation was assessed through the extrinsic/intrinsic orientations within the framework of self-determination theory of motivation. Turkish EFL learners were generally found to be extrinsically motivated, which revealed a moderate level of self-determination. Although learners generally exhibited positive dispositions towards the reasons for learning, increasing learners intrinsic motivation through different activities would result in a higher level of WTC in English. Thus, L2 educators would help learners to acquire a sense of accomplishment, knowledge and stimulation which are all components of intrinsic motivation by means of successful learning experience because a higher level of self-determination means a higher level of WTC.

\section{References}

Bektaş, Ç. Y. (2005). Turkish collage students' willingness to communicate in English as a foreign language. Unpublished Doctoral Dissertation, USA: The Ohio State University.

Clement, R. (1986). Second language proficiency and acculturation: An investigation of the effects of language status and individual characteristics. Journal of Language and Social Psychology, 5, 271-290. https://doi.org/10.1177/0261927X8600500403

Deci, E. L., \& Ryan, R. M. (1985). Intrinsic motivation and self-determination in human behavior. New York: Plenum. https://doi.org/10.1007/978-1-4899-2271-7

Deci, E. L., \& Ryan, R. M. (2000). The" what" and" why" of goal pursuits: Human needs and the self-determination of behavior. Psychological inquiry, 11(4), 227-268. https://doi.org/10.1207/S15327965PLI1104_01

Dörnyei, Z. (1990). Conceptualizing motivation in foreign language learning. Language Learning, 40, 45-78. https://doi.org/10.1111/j.1467-1770.1990.tb00954.x

Dörnyei, Z., \& Ushioda, E. (Eds.). (2009). Motivation, language identity and the L2 self. Bristol, UK: Multilingual Matters. https://doi.org/10.21832/9781847691293

Gardner, R. C. (1985). Social psychology and second language learning: The role of attitudes and motivation. London, England: Edward Arnold.

Ghonsooly, B., Khajavy, G. H., \& Asadpour, S. F. (2012). Willingness to communicate in English among Iranian non-Englih major university students. Journal of language and Social Psychology, 31(2), 197-211. https://doi.org/10.1177/0261927X12438538

Hashimoto, Y. (2002). Motivation and willingness to communicate as predictors of reported L2 use: the Japanese ESL context. Second Language Studies, 20(2), 29-70.

Jung, M. (2011). Korean EFL university students' willingness to communicate in English. Unpublished Doctoral Dissertation. USA: Indiana University.

Kim, H. J. (2004). The relationship among perceived competence, actual competence and language anxiety: Biases in self-ratings of second language proficiency. Modern English Education, 5, 68-85.

Krashen, S. D. (1982). Child-Adult Differences in Second Language Acquisition. Series on Issues in Second Language Research. Massachusetts: Newbury House Publishers.

Lightbown, P. M., Spada, N., Ranta, L., \& Rand, J. (1999). How languages are learned (Vol. 2). Oxford: Oxford university press.

Long, M. (1985). Input and second language acquisition theory. Input in second language acquisition, 377-393.

MacIntyre, P. D. (1994). Variables underlying willingness to communicate: A casual analysis.Communication Research Reports, 11, 135-142. https://doi.org/10.1080/08824099409359951

MacIntyre, P., \& Charos, C. (1996). Personality, attitudes, and affect as predictors of second language communication. Journal of Language and social Psychology, 15, 3-26. https://doi.org/10.1177/0261927X960151001

MacIntyre, P. D., Clement, R., Dörnyei, Z., \& Noels, K. (1998). Conceptualizing willingness to communicate in a L2: a situated model of confidence and affiliation. The Modern Language Journal, 82, 545-62. 
https://doi.org/10.1111/j.1540-4781.1998.tb05543.x

McCroskey, J. C., \& Baer, J. E. (1985). Willingness to communicate: The construct and its measurement. Paper presented at the Speech Communication Association convention, Denver, CO.

McCroskey, J. C., Richmond, V. P. (1991). Willingness to communicate: A cognitive view. In M. Booth-Butterfield (ed.), Communication, Cognition and Anxiety. Sage, Newbury Park, CA, 19-44.

Noels, K. A., Pelletier, L. G., Clement, R., \& Vallerand, R. J. (2000). Why are you learning a second language? Motivational orientations and self-determination theory. Language Learning, 50(1), 57-85. https://doi.org/10.1111/0023-8333.00111

Öz, H. (2016). Role of the ideal L2 self in predicting willingness to communicate of EFL students. Research papers as an Additional Language, 163-182.

Peng, J. E., \& Woodrow, L. (2010). Willingness to Communicate in English: A model in the Chinese EFL classroom context. Language learning, 60(4), 834-876. https://doi.org/10.1111/j.1467-9922.2010.00576.x

Ryan, R. M. (1995). Psychological needs and the facilitation of integrative processes. Journal of personality, 63(3), 397-427. https://doi.org/10.1111/j.1467-6494.1995.tb00501.x

Swain, M. (1985). Communicative competence: Some roles of comprehensible input and comprehensible output in its development. Input in second language acquisition, 15, 165-179.

Vallerand, R. J., Pelletier, L. G., Blais, M. R., Briere, N. M., Senecal, C., \& Vallieres, E. F. (1992). The Academic Motivation Scale: A measure of intrinsic, extrinsic, and amotivation in education. Educational and psychological measurement, 52(4), 1003-1017. https://doi.org/10.1177/0013164492052004025

Vallerand, R. J., Pelletier, L. G., Blais, M. R., Brière, N. M., Senecal, C., \& Vallieres, E. F. (1993). On the assessment of intrinsic, extrinsic, and amotivation in education: Evidence on the concurrent and construct validity of the Academic Motivation Scale. Educational and psychological measurement, 53(1), 159-172. https://doi.org/10.1177/0013164493053001018

Yashima, T. (2002). Willingness to communicate in a second language: The Japanese EFL context. The Modern Language Journal, 86(1), 54-66. https://doi.org/10.1111/1540-4781.00136

\section{Copyrights}

Copyright for this article is retained by the author(s), with first publication rights granted to the journal.

This is an open-access article distributed under the terms and conditions of the Creative Commons Attribution license which permits unrestricted use, distribution, and reproduction in any medium, provided the original work is properly cited. 